\title{
The best argument against kidney sales fails
}

\author{
Luke Semrau
}

Correspondence to

Luke Semrau, Philosophy Department, 111 Furman Hall, Vanderbilt University, Nashville, TN 37240, USA;

Luke.semrau@gmail.com

Received 23 July 2014 Revised 27 August 2014 Accepted 7 September 2014 Published Online First 25 September 2014

\section{ABSTRACT}

Simon Rippon has recently argued against kidney markets on the grounds that introducing the option to vend will result in many people, especially the poor, being subject to harmful pressure to vend. Though compelling, Rippon's argument fails. What he takes to be a single phenomenon - social and legal pressure to vend-is actually two. Only one of these forms of pressure is, by Rippon's own account, harmful. Further, an empirically informed view of the regulated market suggests that this harmful pressure is easily avoided. Thus, the harm that is the lynchpin of Rippon's opposition is neither a necessary feature of the market nor is it likely to play a significant role in its operation.

Much of the opposition to kidney markets is motivated by concern for vendors' well-being. Permitting sales, it is claimed, will lead to exploitation of the poor, coercion by unscrupulous third parties and damage to vendors' health and selfrespect. Though importantly different, all of these challenges seek to justify a market prohibition by appealing to the interests of potential vendors. These objections have a common weakness; many of the harms adduced, proponents counter, may be mitigated or eliminated through market design and regulation. An alternative and potentially much more powerful challenge to kidney sales claims instead that it is the option to vend-not vending itself-that is objectionable.

Simon Rippon has recently developed a promising challenge to kidney sales taking this approach. ${ }^{1}$ Providing the option to vend, even in a wellregulated market, Rippon argues, would cause intolerable harm. He does not claim that vending itself is bad. Rather, his concern is for all of those in poverty who, if kidney sales are permitted, will be subject to harmful social and legal pressures to vend. If vending is normalised, Rippon claims, then the economically disadvantaged will find themselves under pressure to sell. Presently, the most one can offer is one's labour and possessions. But when the market makes human kidneys commodities, one's 'spare' kidney becomes a transferable possession and is treated as such. When circumstances demand ready cash, many will find themselves pressured, by family members or moneylenders, to sell a kidney. To be subject to such social and legal pressure to vend, Rippon maintains, is to be harmed in a morally significant way. And because this harm cannot be avoided through market regulation, a prohibition on sales is justified.

Rippon's argument has attractive features. First, the harm purportedly caused by allowing salessocial and legal pressure to vend-is widespread.
Large segments of the population would be susceptible to such pressure. The benefits of permitting kidney sales may be outweighed if the pressure Rippon has identified is as pervasive and pernicious as he claims. Second, the argument is said to retain its cogency even under moderately idealised conditions. Regulation sufficient to prevent the harmful pressure from arising, he claims, will disqualify precisely those who would be willing to vend. Finally, the argument is not paternalistic. Rippon takes his opposition to kidney sales to be justified on the grounds that such a policy would be autonomously chosen by those affected by it. In light of these features, it is unsurprising that Janet RadcliffeRichards, in her commentary on the piece, describes Rippon's paper as 'probably the best there is in defence of prohibiting the sale of organs'. ${ }^{2}$

Despite its initial appeal, Rippon's challenge is, I argue, unsuccessful. The harmful social and legal pressure that is the lynchpin of his opposition is neither a necessary feature of the market nor is it likely to play a significant role in its operation. After sketching the market proposal I defend, in the second section, I present Rippon's opposition, highlighting his account of the distinctive harm of being pressured to vend. In the third section, I show that this account is incomplete; what Rippon takes to be a single phenomenon-social and legal pressure to vend-is actually two, only one of which is harmful. In the penultimate section, I argue that this harmful pressure is likely easily combated in a regulated market.

\section{THE ERIN AND HARRIS PROPOSAL}

Twenty years ago Charles Erin and John Harris proposed a market design that remains compelling today. ${ }^{3}$ The essential elements are as follows: the market should be monopsonistic, with a single government agency as the only buyer. The price should be fixed and significant; evidence suggests that a compensation package worth $\sim \$ 100000$ is economically feasible. ${ }^{4}$ Kidney allocation may continue based on medical need rather than the ability to pay. Qualified vendors will be in excellent health, provide valid consent and receive suitable medical care throughout. Finally, the market will be geopolitically bounded such that vendors and recipients come from the same catchment area. With a clearer idea of the market proposal on offer, I turn now to present Rippon's challenge.

\section{RIPPON'S CHALLENGE: HOW THE OPTION TO VEND HARMS}

The implications of introducing a kidney market, Rippon insists, would be unwelcome and farreaching. Permitting sales, he claims, would 
'fundamentally change the norms of the relationships of each of us to our bodily organs and to each other'. ${ }^{1}$ He worries that 'if organs can be easily exchanged for cash they will then become commodified, and naturally subject to the kinds of social and legal demands and responsibilities that govern our other transactions in the marketplace'. ${ }^{1}$ The unfortunate and predictable consequence is that many, especially those in poverty, will 'find themselves faced with social or legal pressure to pay the bills by selling their organs'. ${ }^{1}$

Why is social and legal pressure to vend more harmful than comparable pressure to sell one's time or possessions? Rippon offers two reasons: the first is 'the peculiar importance to human beings of our having fully autonomous veto control over any physical incursions on the intimate parts of our bodies by other people'. ${ }^{1}$ Call this the veto claim. 'The second important special feature of organ selling,' Rippon observes, 'is the small but not insignificant life-changing risks involved'. ${ }^{1}$ This risk, he emphasises, is likely to be disproportionately taken by the poor. And being pressured to take an option that unfairly allocates risk is a further harm. Call this the risk claim. The special harm of being socially and legally pressured to vend is then explained by the veto and risk claims.

Rippon grants that measures could be taken to ensure that no one is unduly pressured to vend. He suggests two. First, we might disqualify from vending those who fall below some income level. Second, we might permit all to vend, but disallow any from using the proceeds of their sale to satisfy social and legal demands. These regulations would guarantee that none were subject to undue social or legal pressure to vend. However, they would also reduce the pool of those who are eligible to vend to a class of people unwilling to vend. Thus, Rippon claims, the Erin and Harris proposal, like any, faces an unhappy dilemma: choose regulation sufficient to protect potential vendors from harmful pressure or regulation permissive enough to procure a net increase in transplantable kidneys. ${ }^{5}$

\section{'PRESSURE TO VEND' AND 'PRESSURE WITH THE OPTION TO VEND'}

Central to Rippon's objection is the thought that being pressured to take an option may harm one, even if the option one is pressured to take is itself not harmful. Rippon's example is helpful. 'I do not think that having sex with a celebrity (ordinarily) harms a person', he notes, 'But I do think it would harm a person to be put under significant social or legal pressure to

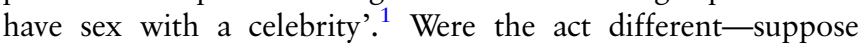
someone was pressured to solve algebraic problems-the pressure to take that option would also be different. I concede that one may be harmed by social and legal pressure to engage in certain acts. But I deny Rippon's claim that this harmful pressure is a necessary consequence of permitting kidney sales. As I will now show, Rippon's opposition mistakenly treats two phenomena as one.

There are two importantly different ways in which one may be subject to 'social and legal pressure to vend'. First, just as Rippon imagines, one may be pressured specifically to sell one's kidney. Pressure to take such an option would invoke the veto and risk claims, and so, according to Rippon, harm those subject to it. I will refer to this simply as pressure to vend. Second, economic need may give rise to social and legal pressure to secure cash. After assessing one's options, one may come to regard vending as the best means of relieving that pressure. Here too we may say one is subject to pressure, but it is of a rather different kind. A critical difference between the two is that in this case no one is pressured to undertake any specific act. I will call this pressure with the option to vend.

Notice, Rippon's account of the harm of being socially and legally pressured to vend applies to only one of these forms of pressure. Pressure to vend invites both the veto claim and the risk claim. It is the character of the act that renders the pressure objectionable. But if the harm of the pressure is partially determined by the act one is pressured to take, then one can only be subject to this harm when one is pressured to act in a specific way. Thus, in cases of pressure with the option to vend, where no one is pressured to perform any specific act, neither the veto claim nor the risk claim is triggered.

Applying this distinction to Rippon's example is illuminating. When we shutter at the thought of someone being socially and legally pressured to have sex with a celebrity, we imagine someone pressured to engage in a specific act. Such pressure is objectionable. But altering the case delivers a different conclusion. Suppose Ann, with student loans coming due, is under economic pressure. After considering pawning heirlooms, and working in retail, Ann decides to become a pornographer. Her first day on set she has sex with a celebrity. Though she was subject to pressure and did have sex with a celebrity, Ann was not subject to pressure to have sex with a celebrity. We may lament Ann's circumstances, but this cannot be because she was pressured in a way that invokes either the veto or the risk claim.

It may be objected that the distinction between pressure to vend and pressure with the option to vend is one without a difference. One may grant, of course, that in some cases the distinction is apt. If my range of options is wide enough, for example, we may sensibly distinguish between the two. However, one may claim that the distinction loses its moral force when one's options are sufficiently constrained. Many people, even if not specifically pressured to vend, may nonetheless feel such pressure de facto. If one's set of options is tiny and the economic pressure one feels is great, then one may, in effect, be subject to pressure to vend. At the core of this objection is the thought that the harm of pressure with the option to vend may be, in some cases, morally similar to the harm of pressure to vend.

This objection misunderstands a conceptual difference between these two ways of being pressured. A distinguishing feature of pressure to vend is that it can be relieved if the option to vend is removed. The harm of that pressure is eliminated when the option is eliminated. But this is not so in the case of pressure with the option to vend. Suppose economic need gives rise to social and legal pressure to secure some cash, and one judges vending to be the best means to relieve it. Removing the option to vend in this case does nothing to remove the pressure. How we ought to respond to these two forms of pressure is quite different. The more acute the pressure to vend is, the greater the pro tanto reason we have to remove that option. However, as economic pressure to take an option increases, so too does the harm caused by eliminating that option. In the former case, removing the option removes the harm. In the latter case, removing the option compounds the harm.

I have distinguished between pressure to vend and pressure with the option to vend, and argued that Rippon's account of the harm of being socially and legally pressured to vend applies only to the former. This is sufficient to refute Rippon's claim that the market will necessarily exert harmful pressure. But a reply is in the offing. Even if pressure to vend is not essential to the market, it may be a probable consequence. If one can show that introducing the option to vend is likely to cause pressure to vend, then one may resist the market on these grounds. Call this 
more modest position: the probable pressure reply. The reply is plausible enough; as one critic of kidney sales observes, the 'instant reward from a kidney sale' may make third parties particularly tempted to exert undue pressure. ${ }^{6}$ The task then, which I turn to now, is to demonstrate that the option to vend is unlikely to give rise to significant levels of pressure to vend.

\section{THE LIMITED ROLE OF 'PRESSURE TO VEND'}

People are vulnerable to pressure when they can easily be made to act so as to procure some good. Pressure to vend, then, will only arise if vending is a reliable means of securing money. There is, however, compelling reason to deny that vending will serve this purpose, and so, compelling reason to deny that the option to vend will give rise to pressure to vend. The probable pressure reply, as I will now argue, is predicated on a misunderstanding of how a regulated market would operate.

According to Rippon, if kidney sales are permitted 'many of us' will consider vending. ${ }^{1}$ If 'organs can be easily exchanged for cash', he claims, 'it is reasonable to assume that your organs would soon enough become economic resources like any other'. ${ }^{1}$ Kidney sales will be so common, Rippon insists, that people struggling to make this month's rent may be pressured to vend. These grim predictions are not merely speculative. Rippon offers, as support for this view of the market, empirical research into markets in Chennai, India. He cites a well-known study that found $96 \%$ of vendors sold to relieve debt, though most remained indebted years later. ${ }^{7} \mathrm{He}$ also cites the work of anthropologist Lawrence Cohen, who found that moneylenders became more aggressive in their collection tactics in areas where vending was common. ${ }^{8}$ The picture that emerges depicts vending not as a means to escape poverty but as a demand accompanying that condition.

Rippon holds what I will call the 'newfound capital' view of kidney commodification, according to which permitting sales would be substantially similar to bestowing all with a surgically accessible token redeemable for $\$ 100000$. Introducing the option to vend would cause dramatic and widespread change. If sales were permitted, everyone would become one abdominal surgery away from potentially transformative sums of cash. Of course, moneylenders would adopt more aggressive tactics. Under these conditions, we should expect the economically disadvantaged to be targeted. With so many people with a kidney to spare-now potentially worth $\$ 100000$ - there would be countless new opportunities to extract handsome sums from unsavvy or otherwise vulnerable actors. In addition, this perspective further supports Rippon's claim that introducing a market will 'fundamentally change the norms of the relationships of each of us to our bodily organs and to each other'. As other critics have also noted, the compensation on offer is significant and could easily distort intimate relations in unexpected ways. ${ }^{9}$

In a regulated market, kidneys will not become 'economic resources like any other'. The 'newfound capital' view is mistaken. An underappreciated fact about the Erin and Harris proposal is that the market would be geopolitically bounded, that is, vendors and recipients would reside in the same region. Such a market would be 'closed' to outsiders. This constraint, combined with the natural demand for kidneys, ensures that vending in any given region will be uncommon. To see this, consider some admittedly crude calculations: As of August 2014, according to the Organ Procurement and Transplantation Network, about 35000 people were added to the waitlist in the USA in 2012. If this is indicative of annual demand, and if we transplant only living kidneys procured on the market, then about 1 in 9000 people would become vendors annually. This natural 'cap', combined with the monopsony's fixed price, makes kidneys quite unlike other economic resources. Each of the first 35000 transplantable kidneys offered annually would fetch $\$ 100000$, and each after that would be refused. This feature of the Erin and Harris proposal renders Rippon's appeal to evidence from India inapt. The market studied there is 'open'; most vendors reside in the slums of Chennai, while most recipients come from elsewhere. As a result, vending is far more common and its societal influence greater.

From this empirically informed view of the market, the sad picture Rippon paints looks unrealistic. Whatever norms govern the relationship between people and their body parts, we have no reason to believe that permitting 1 in 9000 to vend annually will 'fundamentally change' them. Nor should we accept Rippon's claim that vending will be 'simply expected' of those in financial need. The facts of the matter suggest that the practice will never be sufficiently common to influence societal expectations in the ways imagined.

It also becomes clear that introducing the option to vend is unlikely to give rise to pressure to vend. This is because, in short, under a regulated market pressuring others to vend will not reliably result in their vending. Three considerations support this claim. First, as I have argued, because the market is geopolitically bounded, and the demand for kidneys is fixed and low, rates of vending within the general population will necessarily be low. Vending will be rare. Second, because the compensation on offer is appreciable even by middle-class standards, many people, from a range of demographics, are likely to pursue the option. And even if only 1 in 1000 find sales appealing, for every one successful vendor, there would be eight who tried and failed. Vending will be competitive. Finally, the market may be designed to include certain safety features. For example, we may provide potential vendors with the chance to discreetly disqualify themselves at the screening stage or impose a waiting period between when one qualifies to vend and when one is permitted to. The upshot is this: because pressure to vend will not reliably lead to vending, few will bother to exert it.

\section{CONCLUSION}

My central aim has been to refute Rippon's objection without challenging his substantive normative claims. I did not, for example, dispute his account of the harm of being pressured to vend, or question its relative moral significance. Rather, I have argued that the pressure he takes to be pervasive and unavoidable is, in fact, unlikely to feature significantly, if at all in a regulated market.

In closing, I want to emphasise the need for further empirical research. Though I think Rippon's resistance to kidney sales is unfounded, I readily grant that we are in a position of uncertainty. The paucity of relevant evidence means that much of the discussion on kidney sales is largely speculative. There is, unfortunately, nothing speculative about the many thousands of deaths caused by the organ shortage each year or the physical and emotional suffering this brings. For decades, many countries, including the USA, have experimented with donation-only models of organ acquisition. And for decades the shortage of transplantable kidneys has grown more acute. Rather than continue to replicate these sad results, we should take the market proposals on offer seriously. We need to try a different experiment.

Competing interests None.

Patient consent Obtained.

Provenance and peer review Not commissioned; externally peer reviewed. 


\section{REFERENCES}

1 Rippon S. Imposing options on people in poverty: The Harm of a Live Donor Organ Market. J Med Ethics 2014;40:145-50.

2 Radcliffe-Richards J. Commentary by Janet Radcliffe-Richards on Simon Rippon's 'Imposing options on people in poverty: the harm of a live donor organ market'. J Med Ethics 2014;40(3):152-53.

3 Erin C, Harris J. A monopsonistic market: or how to buy and sell human organs, tissues and cells ethically. In: Robinson I, ed. Life and death under high technology medicine. Manchester: Manchester University Press, 1994:134-53.

4 Matas AJ, Schnitzler M. Payment for living donor (vendor) kidneys: a cost-effectiveness analysis. Am J Transplant 2004;4(2):216-21.
5 Rippon S. Organ markets and harms: a reply to Dworkin, Radcliffe Richards and Walsh. J Med Ethics 2014;40(3):155-56.

6 Malmqvist E. Kidney sales and the analogy with dangerous employment. Health Care Anal 2015:23:107-21.

7 Goyal M, Mehta RL, Schneiderman LJ, et al. Economic and health consequences of selling a kidney in India. JAMA 2002;288(13):1589-93.

8 Cohen L. Where it hurts: Indian material for an ethics of organ transplantation. Daedalus 1999:128(4):135-65.

9 Rothman SM, Rothman DJ. The hidden cost of organ sale. Am J Transplant 2006;6(7): 1524-8. 